\title{
An evidence-based review of NXI207 and its potential in the treatment of benign prostatic hyperplasia
}

This article was published in the following Dove Press journal:

Research and Reports in Urology

12 July 2014

Number of times this article has been viewed

\author{
Thomas Kunit \\ Lukas Lusuardi \\ Department of Urology \\ and Andrology, Paracelsus \\ Medical University Salzburg, \\ Salzburg, Austria
}

Correspondence: Thomas Kunit Department of Urology and Andrology, Paracelsus Medical University Salzburg, Müllner Hauptstr 48, 5020 Salzburg, Austria Tel +43 662448257439 Fax +43 6624482 297I

Email t.kunit@salk.at

\begin{abstract}
In elderly men, benign prostatic hyperplasia is often associated with lower urinary tract symptoms, and its prevalence rises with age. Lower urinary tract symptoms can be very bothersome and lead to a decrease in health-related quality of life. Furthermore, benign prostatic hyperplasia is a progressive disease that can lead to serious complications like acute urinary retention. Medical treatment with $\alpha 1$-blockers or $5 \alpha$-reductase inhibitors is recommended by the European Association of Urology. On the other hand, there are some new innovations such as NX1207. The aim of this review is to summarize the published data. NX1207 is a new drug that is administered by transrectal intraprostatic injection under ultrasound guidance. The substance leads to prostate volume reduction and symptomatic improvement. However, patient numbers are still low and currently treatment with NX1207 is still experimental.
\end{abstract}

Keywords: BPH, NX 1207, hyperplasia, LUTS, prostate

\section{Introduction}

In elderly and middle-aged men, benign prostatic hyperplasia (BPH) is a common condition; it is also called benign enlargement of the prostate. It is known that with age the prevalence of BPH increases. BPH is caused by hyperplasia of glandular and stromal tissues of the prostate. ${ }^{1,2} \mathrm{BPH}$ leads to an enlarged gland, which is defined as $>30 \mathrm{~cm}^{3}{ }^{3}$ Among the most common diagnoses of middle-aged men (around 50 years or older), BPH is the fourth most common. ${ }^{4}$ These patients are afflicted by lower urinary tract symptoms (LUTS). The typical symptoms of LUTS are nocturia, frequent urination, urgency, weak stream, and incomplete emptying of the bladder. In cases of incomplete emptying, urinary infections are also typical in these patients. The severity of LUTS is assessed by the validated International Prostatic Symptom Score. ${ }^{5}$ Symptom severity is classified into three different groups: mild (0-7), moderate (8-19), or severe (20-35). As a basic principle, LUTS is caused by bladder outlet resistance due to prostate enlargement. However, the relationship between prostate enlargement and LUTS is not clear at all. An enlarged prostate does not lead to LUTS in every patient. Conversely, not every patient suffering LUTS has BPH. It is well known that nearly every man older than 80 years has histological BPH, but not all of them suffer LUTS. In contrast, LUTS has a prevalence of only $46 \%$ in men older than 70 years. ${ }^{6}$ It is well known that untreated BPH is a progressive condition and LUTS could worsen over time. Age over 50 years, prostate specific antigen $>1.4 \mathrm{ng} / \mathrm{mL}$, prostatic volume $>30 \mathrm{~cm}^{3}$, and an International Prostatic Symptom Score of more than eight are predictive for progression. ${ }^{7}$ Without treatment, BPH can cause significant complications. Acute urinary retention, bladder calculi, and urinary tract infection are typically 
found in these patients. The most dangerous complication of untreated BPH with LUTS is renal impairment. ${ }^{8}$ Before starting treatment in these patients, the European Association of Urology (EAU) recommends a diagnostic workup. This includes medical history, the already mentioned International Prostatic Symptom Score, physical examination, urinalysis, and blood tests. Furthermore, an ultrasound examination of the prostate, bladder, and kidneys should be done. As an extended diagnostic workup, uroflowmetry and a bladder diary can be done. ${ }^{9}$

\section{Treatment}

Current treatment guidelines, such as the EAU guidelines, offer different treatment options. A trial of watchful waiting is recommended for men with mild-to-moderate LUTS. A requirement for this is that LUTS causes no serious health threat in these patients and they are not too bothered by their symptoms. Lifestyle advice such as reduction of fluid intake in the evening or reduction of caffeine and alcohol should be given. Also, double voiding and urethral stripping is useful for these patients. When medical treatment is needed, $\alpha 1$-blockers are the standard medication for this group. However, their effect is not measurable through urodynamic measurement. In contrast, $5 \alpha$-reductase inhibitors can improve flow rates by gland shrinkage. As written in the EAU guidelines, $5 \alpha$-reductase inhibitors should be given to men with moderate-to-severe LUTS in combination with an enlarged prostate $(>40$ $\mathrm{mL})$ or elevated prostate specific antigen concentrations $(>1.4-1.6 \mu \mathrm{g} / \mathrm{L})$. Furthermore, 5 $\alpha$-reductase inhibitors reduce the risk of acute urinary retention and can prevent surgery. Another treatment option mentioned in the EAU guidelines is phosphodiesterase type 5 inhibitors. In the past, phosphodiesterase type 5 inhibitors have been licensed only for the treatment of erectile dysfunction and pulmonary arterial hypertension. Recently, tadalafil - a phosphodiesterase type 5 inhibitor with a long half-life - has been given to patients suffering mild LUTS with or without erectile dysfunction. ${ }^{9}$

\section{NXI 207}

NX1207 is a new drug for the treatment of BPH, but it is still under investigation. It is a new protein that has been shown preclinically to induce apoptosis in cells. ${ }^{10}$ Apoptosis is well known as a program of cell death, which is used to kill unwanted cells. During apoptosis, morphological changes of the cell, disintegration of plasma membrane, cell shrinkage, and development of apoptotic bodies are found. ${ }^{11}$
Cysteine proteases called caspases are crucial for the apoptotic program. These activated proteases can be used as apoptotic markers measured by flow cytometry or fluorescence microscopy. In the early phase of apoptosis, the cell membrane loses its stability. During this process, membrane proteins of the inner leaflet switch to the external surface of the cell. ${ }^{12}$ Annexin $\mathrm{V}$ has a high affinity to these proteins and can therefore be used as an apoptotic marker.

Caspase activation and Annexin V were verified in cells treated with NX1207 in vivo and in vitro; therefore, the investigators concluded that NX1207 leads to apoptotic cell death. The exact mechanism of action is not described in the published papers. The drug is dispensed in phosphate-buffered saline at physiological $\mathrm{pH}$ 7.4. In contrast to all licensed medications for LUTS, NX1207 is not given orally. Before the injection, patients are treated with antibiotics for 3 days and the antibiotic prophylaxis is continued for 7 days. A total of $5 \mathrm{~mL}$ NX1207 is injected directly into the periurethral zone of the prostate, using transrectal ultrasound for guidance. There is not any need for anesthesia. In the published papers, only slight dysuria for 2 days or minimal hematuria was described. A Phase III clinical trial using NX1207 is currently ongoing. Inclusion criteria are a prostatic volume between $30-70 \mathrm{~mL}$ and moderate-to-severe LUTS. A total of $5 \mathrm{~mL}$ NX1207 is injected into both transitional zones of the gland without any anesthesia. Furthermore, no catheterization is needed. ${ }^{12}$

There are two Phase II studies available in the USA. Trial 0014 was the first one. It was designed as a multicenter, randomized, double blind, placebo-controlled study. There were 43 clinical trial sites in the USA. A total of 175 men with clinical BPH were included in the study. Three different doses of NX1207 were examined $-2.5 \mathrm{mg}, 5 \mathrm{mg}$, and $10 \mathrm{mg}$. As a placebo control, saline was used. After randomization, a dose of NX1207 or saline was injected into the gland. The primary endpoint of this study was defined as an improvement in American Urological Association Symptom Index (AUASI) score - measured after 90 days. An improved AUASI score was found in every treatment arm. The lowest concentration of NX1207 (2.5 mg) led to a mean decrease in AUASI score to 11.0 ( $P=0.008$ compared to placebo). With $5 \mathrm{mg}$ NX1207, an improvement to 8.7 ( $P=0.08$ compared to placebo) was found. The highest concentration of NX1207 $(10 \mathrm{mg})$ led to a decrease in AUASI score to $8.1(P=0.17$ compared to placebo). Taking all treatment arms together, the mean improvement was $9.35(P=0.017$ compared to placebo). The secondary endpoint was defined as the volume reduction of the transition zone of the gland. A statistically significant mean prostate volume decrease of $6.8 \mathrm{~mL}$ was 
found compared to placebo. Trial 0016 was the second Phase II study. Like the first study, it was a multicenter and randomized trial. However, this study was designed as a noninferiority study. Thirty-two centers in the USA participated in Trial 0016. NX1207 (2.5 mg) was injected into the prostate and compared with finasteride, a $5 \alpha$-reductase inhibitor. To prove dose-dependent efficacy, 0.125 mg NX1207 was also tested. Eighty-five patients were included in this trial. They were randomized to receive $2.5 \mathrm{mg}$ NX1207, $0.125 \mathrm{mg}$ NX1207, or finasteride. The study was double blinded in term of dosage. As in the first study, the primary endpoint was defined as change in AUASI score. The score was measured 90 and 180 days after treatment. As expected, $2.5 \mathrm{mg}$ NX1207 led to a better AUASI score compared with $0.125 \mathrm{mg}$ after 90 days. In detail, the mean decrease was 9.71 treated with $2.5 \mathrm{mg}$ $(\mathrm{N}=48)$ and 4.29 for $0.125 \mathrm{mg}(\mathrm{N}=7)(P=0.034)$. Compared to finasteride, NX1207 was noninferior. The mean AUASI improvement was 4.13 for finasteride $(\mathrm{N}=24, P=0.001 \mathrm{com}-$ pared to $2.5 \mathrm{mg} \mathrm{NX1207).} \mathrm{As} \mathrm{in} \mathrm{the} \mathrm{first} \mathrm{study,} \mathrm{the} \mathrm{volume}$ reduction of the gland was investigated. A reduction of $4.6 \mathrm{~g}$ was seen with the $2.5 \mathrm{mg}$ NX1207 dosage. After 180 days, the AUASI score was repeated. Full dosage of NX1207 resulted in a mean decrease of 7.51 and was noninferior compared to finasteride. The investigators tried a subgroup analysis, but they did not find a statistical difference in the results between moderate or severe LUTS. In this study, serum protein specific antigen levels and serum testosterone were also measured. However, NX1207 had no influence on these two parameters. Furthermore, no case of impaired sexual function from the injection of NX1207 was described. ${ }^{12}$

Table I Clinical impact summary for NXI 207 on benign prostatic hyperplasia

\begin{tabular}{|c|c|c|}
\hline $\begin{array}{l}\text { Outcome } \\
\text { measure }\end{array}$ & Evidence & Implications \\
\hline $\begin{array}{l}\text { Disease-oriented } \\
\text { evidence }\end{array}$ & $\begin{array}{l}\text { Preclinical studies in } \\
\text { prostate cells }\end{array}$ & $\begin{array}{l}\text { Caspases and Annexin V, } \\
\text { as apoptotic markers, } \\
\text { were detected in } \\
\mathrm{NXI207-treated} \mathrm{cells} \\
\text { in vivo and in vitro. }\end{array}$ \\
\hline $\begin{array}{l}\text { Patient-oriented } \\
\text { evidence }\end{array}$ & $\begin{array}{l}\text { There are two } \\
\text { Phase II studies } \\
\text { available in the USA } \\
\text { (Trials } 0014 \text { and } 0016 \text { ) }\end{array}$ & $\begin{array}{l}\text { NXI } 207 \text { improves AUASI } \\
\text { score after } 90 \text { days and } \\
\text { leads to prostate volume } \\
\text { reduction. }{ }^{9} \text { In the second } \\
\text { study, there was no } \\
\text { inferiority compared to } \\
\text { finasteride. }{ }^{10}\end{array}$ \\
\hline & Ongoing Phase III & Data is not available yet. ${ }^{13}$ \\
\hline $\begin{array}{l}\text { Economic } \\
\text { evidence }\end{array}$ & $\begin{array}{l}\text { Pharmacoeconomic } \\
\text { studies have not yet } \\
\text { been conducted }\end{array}$ & \\
\hline
\end{tabular}

Abbreviation: AUASI, American Urological Association Symptom Index.
Taking all published data together, and although the patient numbers are very low, the level of evidence of publications is Ib.

\section{Conclusion}

All published clinical trials of NX1207 have demonstrated a significant improvement in symptomatic BPH. There was a statistically significant improvement in AUASI scores in patients treated with NX1207 compared to placebo (Table 1). A significant shrinkage in prostatic volume was also shown in these two studies. The authors of the published studies concluded that $5 \mathrm{mg}$ NX1207 seems to be the optimal dosage. On the other hand, the patient numbers are very low. Before giving a general recommendation for NX1207, further studies are needed. There should be a large multicenter placebocontrolled validation study using $5 \mathrm{mg}$ NX1207 with a follow-up of at least 5 years. At the moment, treatment with NX1207 is still experimental.

\section{Disclosure}

The authors report no conflicts of interest in this work.

\section{References}

1. Gratzke C, Schlenker B, Weidlich P, Seitz M, Reich O, Stief CG. [Benign prostatic hyperplasia: background and diagnosis]. $M M W$ Fortschr Med. 2007;149(33-34):25-28. German.

2. Berry SJ, Coffey DS, Walsh PC, Ewing LL. The development of human benign prostatic hyperplasia with age. J Urol. 1984;132(3):474-479.

3. Djavan B, Waldert M, Ghawidel C, Marberger M. Benign prostatic hyperplasia progression and its impact on treatment. Curr Opin Urol. 2004;14(1):45-50.

4. Issa MM, Fenter TC, Black L, Grogg AL, Kruep EJ. An assessment of the diagnosed prevalence of diseases in men 50 years of age or older. Am J Managed Care. 2006;12(Suppl 4):S83-S89.

5. Badia X, García-Losa M, Dal-Ré R, Carballido J, Serra M. Validation of a harmonized Spanish version of the IPSS: evidence of equivalence with the original American scale of the International Prostate Symptom Score. Urology. 1998;52:614-620.

6. Chute CG, Panser LA, Girman CJ, et al. The prevalence of prostatism: a population-based survey of urinary symptoms. J Urol. 1993;150(1):85-89.

7. Barkin J, Giddens J, Incze P, Casey R, Richardson S, Gange S. UroLift system for relief of prostate obstruction under local anesthesia. Can J Urol. 2012;19(2):6217-6222.

8. Fitzpatrick JM. The natural history of benign prostatic hyperplasia. BJU Int. 2006;97(Suppl 2):3-6; discussion 21-22.

9. Oelke M, Bachmann A, Descazeaud A, et al. EAU guidelines on the treatment and follow-up of non-neurogenic male lower urinary tract symptoms including benign prostatic obstruction. Eur Urol. 2013;64(1):118-140.

10. Shore N, Wachs B, Wurzel R, et al. A prospective randomized two dose level comparison of single-injection transrectal intraprostatic NX-1207 and finasteride in men with lower urinary tract symptoms due to benign prostatic hyperplasia. Presented at: 82 nd Annual Meeting of the North Central Section of the American Urological Association; September 24, 2008; Chicago, IL, USA.

11. Kerr JF, Wyllie AH, Currie AR. Apoptosis: a basic biological phenomenon with wide-ranging implications in tissue kinetics. $\mathrm{Br}$ Cancer. 1972;26(4):239-257. 
12. Fadok VA, Voelker DR, Campbell PA, Cohen JJ, Bratton DL, Henson PM. Exposure of phosphatidylserine on the surface of apoptotic lymphocytes triggers specific recognition and removal by macrophages. J Immunol. 1992;148(7):2207-2216.
13. Shore N, Cowan B. The potential for NX-1207 in benign prostatic hyperplasia: an update for clinicians. Ther Adv Chronic Dis. 2011;2(6): 377-383.

\section{Publish your work in this journal}

Research and Reports in Urology is an international, peer-reviewed, open access journal publishing original research, reports, editorials, reviews and commentaries on all aspects of adult and pediatric urology in the clinic and laboratory including the following topics: Pathology, pathophysiology of urological disease; Investigation and treatment of urological disease; Pharmacology of drugs used for the treatment of urological disease. The manuscript management system is completely online and includes a very quick and fair peer-review system, which is all easy to use. Visit http://www.dovepress.com/testimonials.php to read real quotes from published authors

Submit your manuscript here: http://www.dovepress.com/research-and-reports-in-urology-journal 